\title{
MEDIA, INFORMATION AND COMMUNICATION TECHNOLOGY AND SUSTAINABLE DEVELOPMENT IN NIGERIA
}

\section{Lukman Abubakar'1, Professor Junmei², Dr. Mohammed Golam Kaosar ${ }^{3}$}

${ }^{1}$ ICE Department, School of Electrical and Information Engineering. South China University of Technology, Guangzhou, China. Email: Lka00719@yahoo.com

${ }^{2}$ ICE Department, School of Electrical and Information Engineering. South China University of Technology, Guangzhou, China. Email: yjunmei@scut.edu.cn

${ }^{3}$ College of Arts, Business Law and Social Sciences (ABLSS). Murdoch University, Murdoch, Australia. Email: mohammed.kaosar@murdoch.edu.au

Cite this article:

Lukman A., Junmei, Mohammed G.K. (2021), Media, Information and Communication Technology and Sustainable Development in Nigeria. British Journal of Computer, Networking and Information Technology 4(1), 42-50. DOI:

$10.52589 / \mathrm{BJCNIT}-$

GCLFAZM8

\section{Manuscript History}

Received: 17 March 2021

Accepted: 17 April 2021

Published: 6 July 2021

Copyright $\odot 2020$ The Author(s). This is an Open Access article distributed under the terms of Creative Commons Attribution-

NonCommercial-NoDerivatives 4.0 International (CC BY-NC-ND

4.0), which permits anyone to share, use, reproduce and redistribute in any medium, provided the original author and source are credited.
ABSTRACT: This study/paper/research work shows the role of Media, Information and Communication Technology (ICT) and sustainable development in Nigeria; it aimed to improve lives in many other ways, such as through education, skill development, new services creation, innovation and automation, freedom of expression through mass media and expose corrupt practices in Nigeria, although the primary responsibilities of the media is to entertain without words falsely spoken that damage the reputation of one another, inform based on accurate facts and educate on current relevant issues. But not withstanding Media, Information and Communication Technology make a significant impact in sustainable and development in Nigeria.

KEYWORDS: Information and Communication Technology (ICT), Information and communication technologies for development (ICT4D), United Nations - American Standard Public Administration (UN-ASPA), Social Networking Sites (SNS), Television (TV), Agricultural Development Programmes (ADPs), United Nation (UN), Sustainable Development Goals (SDGs) 


\section{INTRODUCTION}

Media, Information and Communication Technology (ICT) are increasingly recognized as the strongest change means humanity has to its disposal. In the recent years, advances in media and ICT have publicly announced a major transformation in human communication, economically, socially, politically, educationally, giving rise to new trends of media and ICT for social communication. Sited as one of the latest of several waves of digital media, social media have introduced new communication patterns, diversified communication content and format, created new forms of expression, fostered freedom, and stimulated a wide participation which has widened the scope of knowledge sharing, innovation and collaboration and allowed citizens from diverse walks of life to have an opportunity to affect changes, convey their views and challenge social norms, thus promoting democracy and fight against corrupt practices in Nigeria.

Moreover, media and ICT are increasingly employed in processes of social changes and development works. Rather, the mobilization of media and ICT has become an instrumental approach for and power to social change. Using media and ICT is about leaderless social movements leading social change - it is the public will mobilization and spheres, as spread through new media outlets and platforms, that pave the way for political change. It is highly likely that the embrace and strategic use of media technologies may further transform them into a driving force for major democratic reforms and other major political changes. The successful implementation of various types of media and ICT for the promotion of social change requires a constant adjustment of strategies to political and national context specific requirements.

The aim of this research is to explore media, ICT and sustainable development in Nigeria. Specifically, I intend to discuss the potential of the-state-of-the-art of media and ICT in facilitating new mediated communication patterns and practices that is sustainable and development in Nigeria. This examines to what extent social media platforms are based on inherently democratic structures of participation and how they have opened new avenues for civic participation and democracy; look at whether independent channels for citizen media have outlived themselves, and the potential of citizen media in meeting the Web 2.0 social media revolution; and look at how social media applications can be utilized in concrete development work or/and in processes of social change. I also endeavor to shed light on some challenges facing the evolving trend of media and ICT in Nigeria.

\section{Core Objectives of this Paper}

Media, Information and Communication Technologies (ICT) has the potential to change new and old forms of economic, political, social activity in Nigeria and Africa at large. In the following ways

$\checkmark$ Assisting the government to define, develop and deliver its programmes and facilitate development based on the new Information Communication Technology (ICT's) strategy(ies);

$\checkmark$ Facilitating business opportunities that are unrivalled in the $21^{\text {st }}$ century;

$\checkmark$ Creating jobs, investment opportunities, infrastructural development, global inclusion and participation within the information society process; 
$\checkmark$ Fighting corruption;

$\checkmark$ Educating the society.

\section{Methodology}

The method employed in this research is the review of existing and relevant documents such as e-journals, ICT and Media platforms, publications, case records and documents reports by government, individuals and organizations (especially on Wiki) in Nigeria.

\section{Media, ICT Access and Use:}

Information and communication technologies for development (ICT4D) refers to the application of information and communication technologies (ICT) toward social, economic, and political development, with a particular emphasis on helping poor and marginalized people and communities. It aims to help in national and international development by bridging the digital divide and providing equitable access to technologies.

Media and ICT development includes many types of infrastructure and services, ranging from telecommunications, such as voice, data, and media services, to specific applications, such as banking, education, or health, to the implementation of electronic government (e-government). Each of these types has its own trends that vary across countries and regions.

The users and non-users of ICTs can be categorized into Non-Users, Indirect Users, Shared Users, and Owner-Use.

$\checkmark$ Non-Users: Individuals with no access to either ICTs or ICT-based information and services. Such individuals may still benefit from ICT4D via the spillover effect situations when other users of ICT increase benefit for the whole community, including the non-users.

$\checkmark \quad$ Indirect Users: Individuals who do not have hands-on access themselves, but can gain access to digital information and services via direct users.

$\checkmark$ Shared Users: Individuals who do not own the technology, but who can directly use ICTs owned by someone else (e.g., by friend, workplace, ICT business, community, etc.).

$\checkmark$ Owner-Users: Individuals who own and use the technology.

Finally, whether directly or indirectly you're benefiting from Media and ICT Development in Nigeria.

\section{How to Sustain Media and ICT Development in Nigeria?}

According to David Edelstein, the interim president and CEO of the Grameen Foundation (May 2015 to May 2016), this is how transformational change may be achieved and sustainable with ICTD.

1. Understand Local Needs

2. Use Appropriate Technology 
3. Create Business Models

4. Measure Social Impact

5. Engage with private sector

6. Innovate Constantly

\section{Applications of Media and ICT}

ICT developmental assistance and projects vary depending on the categorization of the areas of work. Thus, ICT4D has been categorized according to its sectoral and thematic applications. ICT4D sectors are mainly the following:

$\checkmark$ Infrastructure which covers both the vertical and horizontal infrastructure projects;

$\checkmark$ Industry, agriculture and natural resources sector;

$\checkmark$ Social sector which consists of health and education;

$\checkmark \quad$ Private and public sector.

The thematic applications on the other hand, may cover one or more sectors. Examples are environment, gender, participation, sustainable development, governance, sub-regionalization, regionalization and globalization among others.

According to Narasimhan 83, ICT's link between growth and jobs are seen in two different areas that composes the digital economy. Intensive Application which is used to intensify an existing area of economic activity, for example all those sectors which existed prior to ICTs, and extensive application where technology is used to extend the range of economic activity.

\section{Agriculture}

Agriculture is considered to be the most vital sector for ICT intervention. It is considered as the primary economic sector. It produces the most basic of human needs: food, clothing, shelter.

Farmers in the developing countries use ICTs to access price information from national and international markets as well as connect to policy makers and other farmers. There are also smartphone apps that can show the user information about the status of their crops and irrigation system remotely. In livestock farming, cattle-breeding now includes scientific crossbreeding techniques that produce cattle with greatly improved fertility. Having a local radio/TV show will be a great help in informing the community on updates from the agricultural sector. ICTs can also be used for training purposes.

\section{Climate Change and Environment}

The use of ICT in weather forecasting is broad. Weather forecasting offices use mass media to inform the public on weather updates. After tropical storm Ondoy in the Philippines, the Filipino people are more curious and aware about the weather hazards. Meteorological offices are also using advanced tools to monitor the weather and the weather systems that may affect a certain area. 
Monitoring devices include:

$\checkmark$ Weather satellites

$\checkmark$ Weather radars

$\checkmark$ Automatic weather stations

$\checkmark \quad$ Wind profilers

$\checkmark$ Other synoptic data or weather instruments, including Earth Simulator which is used to model climate and weather conditions.

In Africa, flood is one of the major concerns of farmers and citizens. The International Water Management Institute launched the mobile services for flood management, specifically in East Sudan. These mobile services are considered as a next-generation ICT for weather and water information. The tool converts complex satellite sensor information to simple text messages which are sent to farmers and citizens who are using the application informing them about the optimum use of flood water for crop production and their environment. The text messages would also warn the farmers about the flood events which would help them prepare their fields and advise on how to mitigate flood damage in estimating the risk of future flood events.

Climate change is a global phenomenon affecting the lives of people. In times of calamities, information and communication technology is needed for disaster management. Various organisations, government agencies and small and large-scale research projects have been exploring the use of ICT for relief operations, providing early warnings and monitoring extreme weather events. A review of new ICTs and climate change in developing countries highlighted that ICT can be used for:

$\checkmark$ Monitoring: observing, detecting and predicting, and informing science and decision making;

$\checkmark$ Disaster management: supporting emergency response through communications and information sharing, and providing early warning systems; and

$\checkmark$ Adaptation: supporting environmental, health and resource management activities, upscaling technologies and building resilience.

\section{E-government and Civic Engagement}

Media and ICTs, when employed correctly, can be effectively used to aid political development. Often, this progress is achieved by strengthening the cooperation between the government and its citizens, commonly done through interaction. Government agencies, sectors, and organizations take advantage of ICTs to establish and maintain an online presence - a factor that is crucial to information-based societies where the majority of information is accessed, generated and shared via the internet.

The Five Stages of E-government by UN-ASPA (United Nations - American Standard Public Administration) gives insight into how ICTs, websites in particular, help the government in this sociopolitical endeavor: 
$\checkmark$ Stage One: Emerging Web Presence - Websites function as main sources for basic public information on agencies, organizations, elected officials, etc., as well as contact information such as email addresses, phone numbers or office hours. They may also contain FAQs.

$\checkmark$ Stage Two: Enhanced Web Presence - Online presence is expanded through the provision of access to more dynamic and specialized information. A central homepage acts as the main entry point directly linking users to sites of other government branches, agencies, ministries, and so on. It also contains special features such as the search, download, or order of useful documents (official government publications and legislation).

$\checkmark$ Stage Three: Interactive Web Presence - A national government website operates like a portal that allows users to directly visit associated links. Access to specialized databases is also provided. Furthermore, it allows users to download and submit important forms or even schedule appointments with officials. This expansion is also characterized by the emergence of secure sites and user passwords.

$\checkmark$ Stage Four: Transactional Web Presence - Security of sites is ensured. Thus, users have the liberty to carry out government-related transactions online such as obtaining visas, passports, business permits, licenses, etc. In addition, users can customize a portal to fit their specific needs (i.e., direct access to specialized government services).

$\checkmark$ Stage Five: Fully Integrated Web Presence - Due to the nature of cyberspace, the convergence of distinct agencies, ministries, and departments is made possible. All government transactional services are available online, located in one universal portal.

\section{Civic Engagement Through Social Media}

New forms of technology, such as social media platforms, provide spaces where individuals can participate in expressions of civic engagement. Researchers are now realizing that activity such as Twitter users"...that could easily be dismissed as leisure or mundane should be considered under a broader conceptualization of development research."

Social Networking Sites (SNS) are indispensable for it provides a venue for civic engagement for its users to call attention to issues that needs action because of the nature of social media platforms as an effective tool in disseminating information to all its users. Social media can also be used as a support venue for solving problems and also a means for reporting criminal activity or calamity issue that affect the wellbeing of communities. Social media is also used for inciting volunteerism by letting others know of situations in places that require civic intervention and organized activities to make it happen.

\section{ICT for Food Security}

The impact of climate change, energy policies, and the rising of food prices are a few of the causes of food insecurity. The rapid growth of population results in the rise of consumers; agricultural land decreases due to residential and industrial development-all of these contribute to food shortage. Hence, ICT prioritizes e-Agriculture where food security issues are discussed. 
ICTs can contribute to agro-food sustainability transition by increasing resource productivity, reducing inefficiencies, decreasing management costs, and improving food chain coordination. It is known that recently, a great number of farms across the globe are now applying big data and data analytics to enable increase in productivity of agricultural practices. The so-called 'AgInformatics' systems are being heavily invested in by multinationals such as Dow AgroSciences, Deere Co, and Monsanto. They are being applied in a broad variety of farming activities such as equipment maintenance, fields mapping and other operational activities to optimize irrigation, sowing, etc. Some examples of data exchange platforms in agriculture are Fieldscripts, Farm Business Network, Farm Mobile, Agriplace, FIspace.

\section{Sustainability and Scalability}

Currently, the main two perspectives coming out of this area are to emphasize the need for external aid to build infrastructure so that projects can reach viability, and the need to develop and build on local talent.

Establishing a clear and effective initial design serves as a foundation of any development projects. Starting on existing community assets and knowledge promotes collaboration and cooperation among participants resulting to collective decision-making. Thus, involvement of potential participants in the design, implementation, and monitoring and evaluation is valuable. Adding a substantial effect on a project's long-term sustainability is the implementation. The success of project implementation is reflected in a comprehensive evaluation of the expected net benefits. The interdependence between these project components based on a holistic consideration of livelihood systems, needs and opportunities, provides significant contribution to the overall impact of the project on the community.

\section{Sustainable Development Goals}

In 2015, the UN Development Program and the UN Development group postulated a set of 17 goals whose ultimate goal is to transform the world into a better one with emphasis on developing countries. Some of the goals aim to end extreme hunger, poverty, and gender inequality. While none of the Sustainable Development Goals are specifically meant for Information and Communication Technologies, the 2030 Agenda for Sustainable Development believes that it can help at some extent in achieving the SDGs adding that "The spread of information and communication technology and global interconnectedness has great potential to accelerate human progress, to bridge the digital divide and to develop knowledge societies". The International Telecommunication Union also shares this sentiment and considers that the ICTs can "fast forward progress on the SDGs" which would fundamentally improve the lives of the people.

\section{SUMMARY AND CONCLUSION}

The Nigerian media environment has not really favored the farmers especially in terms of access to viable and responsive information on modern practices and innovations in agriculture. While observing that many state Agricultural Development Programmes (ADPs) use few print and electronic mass media in their operation, it is well understood that financial and governmental bottlenecks or lack of awareness of the electronic media and ICT might be responsible. Corruption and inconsistency of media reports as comprehensively reported by 
virtually all Nigerian media are other factors pulling down media and ICT efficiency in Nigeria even though the country's media are fairly well-established. The situation remains so because the media usually expose corrupt acts after the demise of the administrations that perpetrated them (See African Guardian, 1 November 1993; The Guardian, 18 October 1993; Newswatch, 29 October 1993; The Guardian, 13 October 1993; 6 November 1993; and African Concord, 7 March 1994). Beyond the viability of this industry as engendered by Decree No. 38 of 1992 which has liberalized and allowed private license, there are other factors that have combined to whittle down the Nigerian media effects on national development.

The relationship between information technology and development (agriculture) has been established and it is very glaring from our discussions. It is obvious that ICT is increasingly becoming an important part of what we do on farms. Developing countries must adopt the ICT in order to become technologically relevant in the New World. Information is a critical factor in the development of any country. Though constraints like inadequate human capital, inadequate incentives to researcher's/ media men and unreliable data abound in Nigeria; the country can still reap the benefits of ICT and media as envisaged in the National Policy on Information Technology of 2001.

\section{REFERENCES}

A, MAIYE AND K, Mc GRATH, "ICTs and sustainable development: a capability Perspective; AMCIS 2010 proceedings, paper 541. Available at http://aiselaisnet.org/amcis2010/541

ANYASI, F.I, Obiazi, A.M.O and Evbogbai, M.J.E "Information Technology in Engineering" International Conference on Research and Capacity Building"15th to 16th September, 2011. page 133. University of Ghana, East Legon, Accra Ghana.

D, SOUTER. "The Role of Information and Communication Technology (ICT) in

Democratic Development. Journal of Policy Regulation and Strategy for

Telecommunication Information and Media, 1999. 1:8;408.

Heeks, Richard (2006). "Introduction: Theorizing ICT4D research". Information

Technologies and International Development. 3 (3). Retrieved 7 September 2016.

Heeks, Richard (2008). "ICT4D 2.0: The Next Phase of Applying ICT for International

Development". IEEE Computer. 41 (6): 26-33. doi:10.1109/MC.2008.192.

Heeks, Richard (2009). "The ICT4D 2.0 Manifesto: Where Next for ICTs and International

Development?" (PDF). Development Informatics Group; Institute for Development

Policy and Management. Retrieved 7 September 2016.

Heeks, Richard (30 March 2016). "From ICT4D to Digital Development?". ICTs for

Development. Retrieved 9 September 2016.

Heeks, Richard. "The Godfather of ICT4D, and ICT4D's First Computer".

M.C, ANAEKWE, "Information Technology: A tool for Sustainable Development in Science Education. Global Communicator, 2008. 1(1):32. 
British Journal of Computer, Networking and Information Technology

ISSN: 2689-5315

Volume 4, Issue 1, 2021 (pp. 42-50)

www.abjournals.org

Rogers, E. M. (1976). Communication and Development: The Passing of the Dominant Paradigm. Communication Research, 3(2), 213-240. https://doi.org/10.1177/009365027600300207

UNDP. (2001). Human Development Report. http://www.undp.org/hdr 2001/. Unwin, Tim (2009). ICT4D: Information and Communication Technology for juliana uribe Development. Cambridge University Press. p. 9. 